Fastabiq: Jurnal Studi Islam

ISSN 2723-0228

Volume 1 Nomor 1 Juni 2020

Halaman 1-19

\title{
ETIKA BISNIS DALAM AKAD MUDHÂRABAH (Studi di Baitul Maal wa at-Tamwil Tamzis Kantor Cabang Pembantu Bandung Ibu Inggit Garnasih)
}

\author{
Annisa Eka Rahayu \\ Magister Ekonomi Syariah, Pascasarjana Universitas Islam Bandung \\ annisaeka1397@gmail.com
}

\begin{abstract}
Baitul Maal wa at-Tamwil Tamzis Inggit Garnasih is a Sharia Cooperative that is very strategically located with Micro business in Kebon Kelapa Market Bandung. That small capital deficit entrepreneurs can do mudhârabah financing at Tamzis. The number of small entrepreneurs who do the financing Tamzis needs to be careful in running his business. Considering that the mudhârabah contract is a contract of cooperation between Shahibul Mal and Mudharib, both must hold to full trust, it is necessary to implement Islamic ethics in carrying out the contract. The purpose of this study was to eximine the susccesful implementation of business ethics in mudhârabah contracts at BMT TAMZIS KCP Bandung Inggit Garnasih. The research method is based on a sociological juridical approach. Research methods conducted based on the normative juridical approach. This research is understood as filed research, which is collecting documentation data that is located in BMT TAMZIS KCP Bandung Inggit Garnasih. The research used is analytical descriptive, that is, research to describe current problems or based on reality in the field, and the type of data used in this research, namely primary data, material or data and secondary data in the form of supporting books. related to the object. The results showed that the Islamic business ethics carried out in the mudhârabah contract at BMT TAMZIS KCP Bandung Inggit Garnasih showed an example of its success in helping members (customers) who are traders in the Kebon Kalapa ITC market environment.
\end{abstract}

Keywords: BMT, Islamic Business Ethics, and Mudhârabah.

\begin{abstract}
Abstrak
Manusia dalam menjalankan bisnis membutuhkan seperangkat norma atau nilai yang dapat dijadikan patokan yang sering disebut sebagai etika. Etika adalah pelumas aktivitas manusia di dunia bisnis. Khususnya bisnis yang bekerjasama seperti Mudhârabah yang dilakukan di Baitul Maal wa at Tamwil Tamzis Bandung. Bagi umat Islam, nilai-nilai luhur ini dapat ditemukan dalam ajaran Islam. Menimbang bahwa kontrak mudhârabah adalah kontrak kerjasama antara Shahibul Mal dan Mudharib, dan keduanya harus berpegang pada kepercayaan penuh, perlu untuk menerapkan etika Islam dalam melaksanakan kontrak. Tujuan penelitian ini untuk mengkaji keberhasilan penerapan etika bisnis pada akad mudhârabah di BMT TAMZIS KCP Bandung lbu Inggit Garnasih. Metode penelitian yang dilakukan berdasarkan kepada pendekatan yuridis normatif. Penelitian yang digunakan adalah deskriptif analitis, yaitu penelitian untuk menggambarkan masalah yang ada pada masa sekarang atau berdasarkan kenyataan di lapangan, serta jenis data yang dipergunakan dalam penelitian ini, yaitu data primer, dan data sekunder dalam bentuk buku-buku penunjang yang berkaitan dengan objek. Penelitian ini dipahami sebagai penelitian lapangan, yaitu dengan mengumpulkan data dokumentasi yang berada di BMT Tamzis KCP Bandung Inggit Garnasih. Hasil penelitian menunjukan bahwa Etika bisnis Islam yang dijalankan dalam akad Mudhârabah di BMT TAMZIS KCP Bandung Inggit Garnasih telah menunjukan contoh keberhasilannya dalam membantu para anggota (nasabah) yang merupakan kalangan para pedagang di lingkungan Pasar ITC Kebon Kalapa.
\end{abstract}

Kata kunci: BMT, Etika Bisnis Islam, dan Mudhârabah

\section{PENDAHULUAN}

Ekonomi merupakan suatu elemen yang tidak bisa dilepaskan dari kehidupan. Sistem ekonomi Islam adalah ekonomi yang berdasarkan ketuhanan. Sistem ini bertitik tolak dari Allah, 


\section{Fastabiq: Jurnal Studi Islam \\ ISSN 2723-0228}

Volume 1 Nomor 1 Juni 2020

bertujuan akhir kepada Allah dan menggunakan yang tidak lepas dari syariat Allah. ${ }^{1}$ Sistem ekonomi Islam berbeda dengan sistem ekonomi lainnya, sebab ekonomi Islam merupakan sistem ekonomi yang dibangun berlandasakan nilai-nilai dan norma keagamaan yang bersumber dari al-Qur'an, hadits dan juga ijtihad para ulama. Di sinilah letak hakikat ekonomi Islam yang terlihat pada ciri khasnya yang bersandar pada sumber ajaran Islam dalam bingkai aturan syariah.

Sebagaimana ekonomi konvensional, ekonomi Islam membicarakan tentang aktivitas manusia dalam mendapatkan dan memenuhi kebutuhan hidupnya. ${ }^{2}$ Dalam transaksi bisnis Islam khususnya di Lembaga Keuangan Syariah, embrio kepercayaan dimulai denngan pelaksanaan transaksi yang sesuai dengan al-Qur'an dan hadits Nabi Saw. Segala pelaksanaan transaksi tersebut bertujuan untuk meniadakan angka penipuan, persengketaan, ataupun segala macam dampak negatif yang timbul dari suatu transaksi. ${ }^{3}$

Salah satu aktivitas ekonomi masyarakat saat ini adalah dengan munculnya Lembaga Keuangan Syari'ah (LKS). Munculnya Lembaga Keuangan Syariah merupakan hasil pemikiran dan pemhaman umat Islam terhadap prinsip dan fikih muamalah yang kemudian diimplementasikan dalam sebuah pranata ekonomi dalam bentuk lembaga keuangan bank dan non bank. Salah satu lembaga non bank yaitu Baitul Maal wa Tamwil atau yang lebih dikenal dengan BMT. BMT merupakan lembaga keuangan non bank (mikro) yang dioperasikan dengan prisnip bagi hasil, menumbuhkembangkan bisnis usaha mikro dalam rangka mengangkat derajat dan martabat serta membela kepentingan kaum fakir miskin, ditumbuhkan atas prakarsa dan modal awal dari masyarakat setempat dengan berlandaskan sistem ekonomi yang salâm (keselamatan) yang berintikan kedamaian, keadilan, dan kesejahteraan. ${ }^{4}$

Keberadaan BMT dapat dipandang memiliki dua fungsi utama, yaitu sebagai media penyalur pendayagunaan harta ibadah seperti zakat, infak, sedekah dan wakaf serta dapat pula berfungsi sebagai institusi yang bergerak di bidang investasi tang bersifat produktif sebagaimana layaknya bank. ${ }^{5}$ Pada fungsi kedua ini dapat dipahami bahwa selain berfungsi sebagai lembaga keuangan, BMT juga berfungsi sebagai lembaga ekonomi. Sebagai lembaga keuangan, BMT bertugas menghimpun dana dari masyarakat (anggota BMT) yang memercayakan dananya disimpan di BMT dan menyalurkan dana kepada masyarakat (anggota BMT).

Salah satu pembiayaan yang terdapat pada BMT adalah pembiayaan Mudhârabah. Dari pembiayaan mudhârabah tersebut BMT memberikan persyaratan dan alur pembiayaan. Namun, pasti ada permasalahan yang muncul pada hampir semua lembaga pembiayaan termasuk BMT, salah satunya yaitu ketika anggota atau nasabah tidak dapat mengembalikan angsuran pembiayaan. Hal ini disebabkan karena anggota atau nasabah tidak memenuhi aturan-aturan yang diberikan pihak BMT. Pihak BMT yang sebelumnya menilai character nasabah diharapkan dapat menganalisis karekter nasabah itu sendiri. Dalam arti nasabah atau anggota BMT tidak memiliki itikad dan akhlak yang baik dalam melakukan transaksi pembiayaan mudhârabah. Karena itu akhlak merupakan modal utama dalam melakukan transaksi. Akibat dari anggota memiliki akhlak yang baik dalam pembiayaan, maka akan berimbas pada BMT itu sendiri yang dapat menimbulkan pembiayaan bermasalah. Sehingga 


\section{Fastabiq: Jurnal Studi Islam}

ISSN 2723-0228

Volume 1 Nomor 1 Juni 2020

dalam konteks moral dan etika, sebuah bisnis yang baik adalah bisnis yang mengedepankan dan menjunjung tinggi nilai-nilai etika. ${ }^{6}$

Islam sebagai way of life adalah ajaran yang lengkap dan universal, aturannya jelas dan aplikatif. Tak ada satupun sisi kehidupan manusia yang tidak diatur dalam Islam, termasuk dalam dunia bisnis. Sayangnya banyak perusahaan yang belum menerapkan etika dalam bisnisnya, sehingga yang terjadi adalah pelanggaran etika bisnis dan persaingan yang tidak seimbang antara pemodal kuat dengan pemodal lemah, ada banyak ketidakadilan, munculnya moral hazard, wanprestasi, penyuapan dan lain-lain. Oleh karena itu perlu pengintegrasian etika ke dalam dunia bisnis. Apalagi banyak penelitian yang menunjukkan adanya hubungan yang positif antara etika bisnis dengan kinerja perusahaan.

Etika bisnis yang bersumber dari spirit ajaran Islam hadir sebagai wujud antisipasi terhadap banyaknya penyimpangan dan kecurangan dalam dunia bisnis misalnya penipuan, penggelapan, dan pemerasan yang kemudian menjadi latarbelakang munculnya etika bisnis Ketika seseorang maupun lembaga melakukan pelanggaran terhadap norma dan etika dalam berbisnis, terkadang mungkin saja akad transaksi yang dilakukan sah secara hukum, namun transaksi tersebut tidak akan mendapat keberkahan.

BMT Tamzis Cabang Bandung Ibu Inggit Garnasih memiliki peran yang cukup penting bagi para UKM di Pasar ITC Bandung. Namun perlu diketahui juga BMT Tamzis Ibu Inggit Garnasih memiliki pengaruh yang cukup tinggi terhadap UKM di pasar ITC. Banyak juga anggota yang melakukan pembiayaan ini hingga berulang-ulang, karena keterbatasan modal yang dimiliki. Dari banyaknya anggota yang melakukan pembiayaan, tentunya BMT Tamzis perlu memiliki sifat kehatihatian dalam melakukan pembiayaan. Dari pemaparan di atas, penulis berpendapat bahwa perlu adanya penelitian mengenai bagaimana penerapan etika bisnis pembiayaan mudhârabah yang diterapkan oleh BMT Tamzis. Maka dari itu penulis tertarik untuk menulis mengenai penerapan etika bisnis dalam akad mudhârabah, agar tidak terjadinya moral hazard, wanprestasi dan sebagainya pada pembiayaan di BMT Tamzis KCP Bandung Ibu Inggit Garnasih.

Dalam penelitian ini peneliti memilih BMT TAMZIS KCP Bandung Ibu Inggit Garnasih sebagai obyek penelitian, karena (1) pertimbangan yuridis, yaitu BMT Tamzis memiliki badan hukum Koperasi sehingga hal ini dapat memberikan kepastian hukum bagi BMT maupun nasabah, (2) secara filosofis, BMT merupakan Lembaga Keuangan yang menerapkan prinsip-prinsip syariah dalam melaksanakan aktivitasnya, dan (3) secara sosiologis, letak BMT TAMZIS KCP lbu Inggit Garnasih berdekatan dengan pasar ITC Kebon Kelapa Bandung, yang mana BMT TAMZIS KCP Bandung lbu Inggit Garnasih dapat membantu pergerakan roda perekonomian para pengusaha kecil di daerah tersebut demi pengembangan ekonomi mikro.

Pada dasarnya kantor pusat BMT TAMZIS terletak di Wonosobo, Jawa Tengah. BMT TAMZIS KCP lbu Inggit Garnasih ini merupakan salah satu kantor cabang dari beberapa kantor cabang yang ada di Indonesia. Kehadiran BMT TAMZIS KCP Ibu Inggit Garnasih ini dapat membantu masyarakat menengah kebawah khususnya para UKM untuk mengembangkan perekonomian daerah tersebut agar lebih maju. Dikarenakan lokasi BMT TAMZIS yang strategis dan berdekatan dengan pasar ITC 
Fastabiq: Jurnal Studi Islam

ISSN 2723-0228

Volume 1 Nomor 1 Juni 2020

Kebon Kelapa yang mayoritas penduduk notabenenya adalah para pedagang, maka TAMZIS ini mengedepankan dan membantu mereka yang defisit dana untuk pengembangan usaha mereka pada sektor perdagangan.

Dengan demikian BMT TAMZIS KCP Bandung Ibu Inggit Garnasih ini memiliki peran penting pengaruhnya yang cukup tinggi terhadap perkembangan UKM di pasar ITC Kebon Kelapa Bandung. Ini dibuktikan dengan banyaknya anggota yang melakukan pembiayaan dari BMT TAMZIS KCP Bandung lbu Inggit Garnasih ini secara berulang-ulang. Jumlah anggota atau nasabah di BMT TAMZIS KCP Bandung Ibu Inggit Garnasih ini sebanyak 41 orang yang melakukan pembiayaan mudhârabah dengan sebagian besar anggota melakukan transaksi dengan baik. Yang mana 32 orang (78\%) anggotanya berhasil menjalankan transaksi dengan lancar yang besarnya ratusan juta rupiah.

Hal ini menunjukan adanya keberhasilan etika bisnis berspiritkan ajaran Islam dalam akad Mudhârabah yang diterapkan di BMT KCP Bandung lbu Inggit Garnasih. Banyaknya anggota yang melakukan pembiayaan, tentunya BMT Tamzis perlu memiliki sifat kehati-hatian dalam melakukan pembiayaan dengan berdasarkan etika bisnis islami.

\section{METODE PENELITIAN}

Metode penelitian yang dilakukan berdasarkan kepada pendekatan yuridis sosiologis, yaitu dengan mengamati dan mengkaji data atau bahan yang ada di lapangan. Sekaligus pula dilengkapi pendekatan yuridis normatif, yaitu dengan mengkaji atau menganalisis data sekunder yang berupa bahan-bahan hukum sekunder dengan memahami hukum sebagai perangkat peraturan atau norma positif di dalam perundang-undangan yang berlaku.

Penelitian ini dipahami sebagai penelitian lapangan, yaitu dengan mengumpulkan data dokumentasi yang berada di BMT TAMZIS. Penelitian yang digunakan adalah deskriptif analitis, yaitu penelitian untuk menggambarkan masalah yang ada pada masa sekarang atau berdasarkan kenyataan di lapangan, dengan mengumpulkan data, menyusun, mengklasifikasikan, menganalisis, dan menginterpretasikan. Jenis data yang dipergunakan dalam penelitian ini, yaitu data sekunder, yakni berupa berupa buku-buku penunjang yang berkaitan dengan Etika Bisnis Islam dan Pembiayaan Mudhârabah. Metode analisis data yang digunakan dalam penelitian ini adalah metode kualitatif, yaitu analisis terhadap data sekunder dilakukan dengan teori yang kemudian diterapkan secara deduktif terhadap fokus permasalahan.

\section{PEMBAHASAN}

\section{Konsep Etika Bisnis dalam Islam}

Etika berasal dari bahasa Yunani yang berarti "ethos" yang berarti costum atau kebiasaan atau karakter. Secara istilah etika ialah ilmu tentang apa yang baik dan apa yang buruk dan sebagainya serta prinsip-prinsip umum yang membenarkan kita untuk mengaplikasikannya atas apa saja. ${ }^{7}$ Dalam Islam etika lebih dikenal dengan akhlak, dan makna akhlak lebih memiliki nilai dan makna yang sangat spesifik mengenai karakter manusia. Akhlak merupakan bentuk jamak dari khulûq 


\section{Fastabiq: Jurnal Studi Islam}

ISSN 2723-0228

Volume 1 Nomor 1 Juni 2020

yang berarti keadaan jiwa yang mengajak seseorang untuk melakukan perbuatan tanpa memikirkan sebelumnya. Menurut Imam al-Ghazậli akhlak adalah sifat yang tertanam kuat dalam diri. Dari situ muncullah perbuatan dengan spontan tanpa melalui pemikiran dan pertimbangan, jika perbuatan atau perilaku yang keluar darinya baik, maka akhlaknya baik, sebaliknya jika perbuatan atau perilakunya buruk maka akhlaknya buruk."

Adapun yang dimaksud dengan bisnis adalah segala aktivitas yang melibatkan penyediaan barang ataupun jasa yang dibutuhkan oleh masyarakat. Dapat dikatakan, bahwa etika bisnis Islam adalah seperangkata aturan moral yang berkaitan dengan baik dan buruk, benar atau salah, bohong dan jujur yang bertujuan untuk mengendalikan manusia dalam melakuakan aktivitas ekonomi. Bisnis merupakan bagian inheren yang amat penting bagi suatu masyarakat. Dalam menjalankan bisnis dan agar tidak saling merugikan, manusia memerlukan seperangkat aturan yang dapat dijadikan pegangan dalam aktivitas bisnisnya. ${ }^{9}$

Etika bisnis Islam hadir sebagai wujud antisipasi terhadap banyaknya penyimpangan dan kecurangan dalam dunia bisnis misalnya penipuan, penggelapan, dan pemerasan yang kemudian menjadi latarbelakang munculnya etika bisnis. Etika bisnis dianggap memiliki seperangkat alat yang mampu untuk mengubah hal-hal yang negatif menjadi positif dalam dunia bisnis. Konsep etika bisnis dalam Islam mempunyai perbedaan dengan konsep etika konvensional. Perbedaan itu muncul karena dasar pijakan dan dasar berpikir masing-masing berbeda. Hal ini termaktub dalam firman Allah Swt mengenai perintah melakukan kegiatan etika bisnis dalam Islam terdapat dalam Surat al-Jumuah [62]: 10.

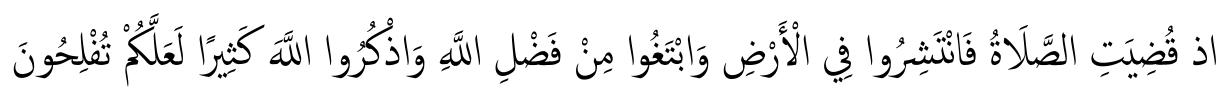

"Apabila telah ditunaikan shalat, maka bertebaranlah kamu di muka bumi; dan carilah karunia Allah dan ingatlah Allah banyak-banyak supaya kamu beruntung."( al-Jumuah [62] :10).

Nash di atas merupakan tujuan dari seseorang melakukan kegiatan ekonomi yaitu mengembalikan kesadaran manusia untuk menjadi manusia yang paripurna dan berakhlak sebagaimana yang di perintahkan oleh Allah Swt, dengan kecenderungan berbuat baik tanpa beban dan paksaan. Etika bisnis Islam didasarkan pada nilai-nilai luhur yang ditemukan dalam sumber-sumber ajaran Islam seperti al-Qur'an, hadits Nabi Saw, dan ijma' para ulama dan qiyas. Dari sumber-sumber ini kita bisa memperoleh etika bisnis Islam, seperti nilai-nilai moralitas yang menyeru manusia pada kebenaran dan kebaikan, kesabaran dan akhlak, setua mencegah mereka dari kepalsuan, penipuan, kecurangan, kejahatan, dan kemungkaran.

\section{Konsep Akad Mudhârabah}

Mudhârabah adalah akad musammah, yaitu akad yang telah disebutkan syara' sendiri namanya, demikian pula aturan-aturannya secara umum. Mudhârabah adalah akad kerjasama dalam perniagaan yang telah ada sebelum Nabi Muhammad Saw. diangkat menjadi rasul Allah. Mudhârabah disebut juga al-qirad. ${ }^{10}$ Menurut Imam an-Nawawi dalam kitab ar-Raudhah IV/97, al-qirad, al- 


\section{Fastabiq: Jurnal Studi Islam}

ISSN 2723-0228

Volume 1 Nomor 1 Juni 2020

muqaradhah, dan al-mudhârabah adalah satu makna yaitu penyerahan harta (modal) terhadap seseorang untuk diperniagakan atau digolangkan sedangkan keuntungannya dibagikan di antara mereka (pemodal dan yang diberi modal).

Di dalam Kompilasi Hukum Ekonomi Syari'ah (KHES) Buku II, Bab I Pasal 20, mudhârabah adalah kerjasama antara pemilik dana atau penanam modal dan pengelola modal untuk melaksanakan usaha tertentu dengan pembagian keuntungan berdasarkan nisbah. Mudhârabah berasal dari kata dharb berarti memukul atau berjalan. Pengertian memukul atau berjalan ini lebih tepatnya adalah proses seseorang memukulkan kakinya dalam menjalankan usaha. ${ }^{11}$

Akad mudhârabah merupakan akad kerjasama usaha yang dilakukan antara dua pihak atau lebih dengan modal usaha dari salah satu pihak (tanpa ikut serta dalam bisnis) dan keahlian usaha dari pihak laun (tanpa ikut dalam penyertaan modal). Kerjasama antara pemodal (rabb al-mal/ shaib al-maal) dan pelaku usaha yang disebut dengan syirkah mudhârabah. Oleh karena itu, dalam kitab lisan al-'Arab dijelaskan bahwa syirkah mudhârabah adalah usaha-bisnis yang dilakukan oleh pihak tertentu atas dasar modal dari pihak lain yang dilakukan berdasarkan kepercayaan (amanah/ trust). ${ }^{12}$

Bisnis dilakukan oleh pelakunya guna mendapatkan keuntungan yang akan dibagikan secara proporsional atas sesuai kesepakatan di antara pihak-pihak yang ber-syirkah. Akan tetapi, bisnis yang dilakukan akan memiliki banyak kemungkinan; setidaknya ada tiga kemungkinan; 1) laba/untung(ribh/profit),; 2) rugi/khasarah/lost; 3) balik modal (tidak untung dan tidak rugi dari segi jumlah modal). Dalam syirkah mudhârabah, keuntungan dibagi antara pemilik modal (shahib al-mal) dan pelaku usaha/pebisnis/mudharib berdasarkan nisbah yang disepakati. Kerugian dibebankan hanya kepada shahib al-mal, kecuali kerugian tersebut terjadi karena kelalalian mudharib. ${ }^{13}$ Landasan hukum mudhârabah mengenai kebolehannya akad mudhârabah diantaranya.

Adapun dalil mengenai akad mudhârabah dalam Al-Qur'an dan hadits Nabi Muhammad Saw., di antaranya:

a. Dalam A.S. al-Muzzamil (73) : 20, Allah berfirman:

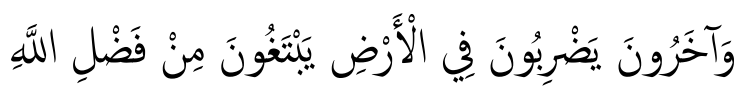

“...(Di antara kamu ada) orang-orang yang berjalan di muka bumi mencari sebagian karunia Allah..." (Q.S al-Muzzamil (73) : 20).

Landasan praktik mudhârabah didasarkan pada akar katanya yaitu dharb. Juga ditunjukkan dengan kalimat yadharibûna fil ardhi yabtaghûna min fadlillaâhi di Q.S. al-Muzzamil ayat 20, yang sama dengan akar kata mudhârabah, yang berarti menjalankan suatu usaha, "orang-orang yang berjalan di muka bumi nencari sebagian karunia Allah." yang memang menunjukkan sebagai upaya seseorang untuk mecari rezekinya di jalan Allah Swt. ${ }^{14}$

b. Hadits yang berupa taqrir atas perbuatan sahabat, yaitu: 


\section{Fastabiq: Jurnal Studi Islam}

ISSN 2723-0228

Volume 1 Nomor 1 Juni 2020

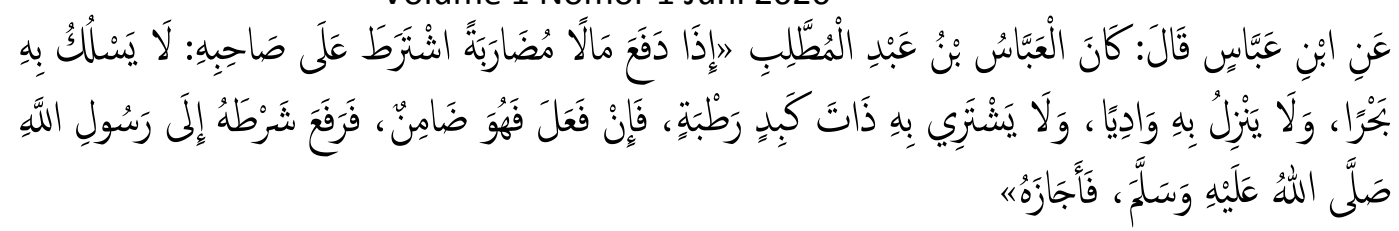

Abbas Ibn Abd Muthalib jika menyerahkan harta sebagian mudhârabah itu mensyaratkan kepada mudharib nya agar tidak mengarungi lautan dan tidak menuruni lembah, serta tidak membeli hewan ternak. Jika persyaratan itu dilanggar, ia (mudharib) harus menanggung risikonya. Ketika persyaratan yang ditetapkan Abbas itu didengar Rasulullah, beliau membenarkannya.

c. Hadits riwayat Ibn Majah dari Shuhaib, yaitu:

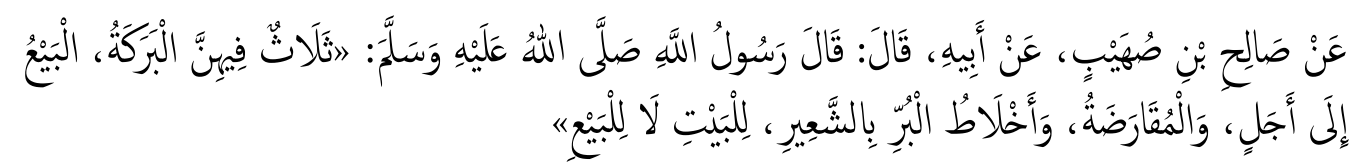

"Nabi bersabda, "Ada tiga hal yang mengandung berkah: jual beli-beli tidak secara tunai, muqaradah (mudhârabah), dan mencamput gandum dengan jewawut untuk keperluan rumah tangga, bukan untuk dijual."

Dalam melakukan transaksi, tentunya agar menjaga sahnya transaksi tersebut maka dalam transaksi ini terdapat rukun dan syarat. Jumhur Ulama menyatakan, bahwa rukun mudhârabah terdiri atas ; 1) Orang yang melakukan akad; 2) Modal; 3) Keuntungan; dan 4) Akad. Adadpun syarat-syarat dari mudhârabah itu sendiri. ${ }^{15}$

a. Bagi pihak yang berakad, terkait dengan orang yang melakukan transaksasi haruslah orang yang cakap bertindak hukum dan cakap diangkat sebagai wakil. Pada satu sisi, posisi orang yang akan mengelola modal adalah wakil dari pemilik modal. Itulah sebabnya, syarat-syarat seorang wakil juga berlaku bagi pengelola modal dalam akad mudhârabah.

b. Terkait dengan modal, disyaratkan modal harus berbentuk; uang, jelas jumlahnya, tunai dan diserahkan sepenuhnya kepada mudharib.

c. Terkait dengan keuntungan, disyaratkan bahwa pembagian keuntungan haruslah jelas diambil dari keuntungan seperti setengah (1/2), sepertiga (1/3), atau seperempat (1/4).

d. Terkait dengan Akad, untuk syarat akad mengikuti syarat akad pada umumnya, yaitu harus jelas shigatnya dan ada kesesuaian antara ijab dan kabul.

Akad mudhârabah dibedakan menjadi dua, yaitu; 1) akad mudhârabah-mutlaqah (mudhârabah tidak terikat/bebas) dan 2) akad mudhârabah-muqayyadah (mudhârabah terikat). Karena mudhârabah sama dengan qiradh terdapat terminologi lainnya yang hampir sama dengan ragam mudhârabah tersebut. Mudhârabah mutlaqah sama dengan qiradh 'am, sedangkan mudhârabah muqayyadah sama dengan qiradh khash. Perbedaan keduanya dijelaskan oleh Wahbah al-Zuhaili sebagai berikut.

a. Mudhârabah tidak terikat adalah penyerahan modal dari shaib al-mal kepada mudharib guna melakukan usaha (bisnis) tanpa ditentukan jenis usahanya, tempatnya, waktunya, sifat bisnisnya, dan/atau pihak yang melakukan usahanya. 


\section{Fastabiq: Jurnal Studi Islam}

ISSN 2723-0228

Volume 1 Nomor 1 Juni 2020

b. Mudhârabah terikat adalah akad mudhârabah yang berupa penyerahan modal dari shaib al-mal kepada mudharib untuk melaksanakan usaha (bisnis) yang ditentukan jenis usahanya, tempatnya, waktunya, sifat bisnisnya, dan/atau pihak yang melakukan usahanya. ${ }^{16}$

\section{Penerapan Etika Bisnis Islam dalam Akad Mudhârabah}

Pembiayaan akad mudhârabah merupakan akad pembiayaan yang harus memenuhi syarat analisis kelayakan. Kelayakan yang dilakukan bertujuan agar pihak BMT mengetahui kondisi dan karakter anggota BMT agar anggota tidak melakukan hal yang melanggar dalam akad, seperti kasus wanprestasi. Berikut analisis kelayakan beserta penerapan etika bisnis Islam dalam akad mudhârabah.

a. Jujur potensi keberkahan syirkah

Bergabung dalam syirkah untuk mewujudkan keuntungan bersama, termasuk tolong menolong dalam kebaikan. Jujur dalam melakukan syirkah atau kerjasama seperti mudhârabah termasuk sebab keberkahan untuk mendapatkan rizki. ${ }^{17}$ Dalam hadits Qudsi, dari Abu Hurairah radiyallahu 'anhu, dari Nabi shallallahu'alaihi wa Sallam, beliau bersabda:

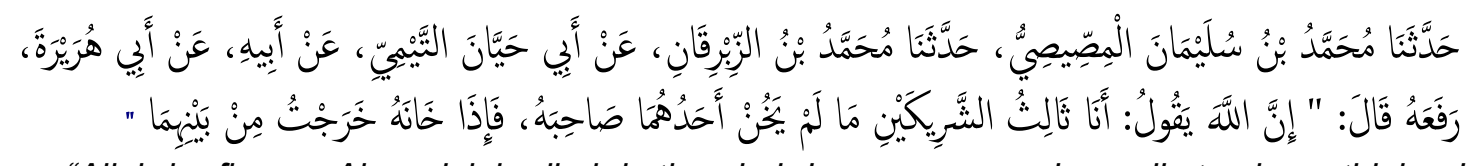

"Allah berfirman, Aku adalah pihak ketiga dari dua orang yang berserikat selama tidak ada yang mengkhianati pasangannya. Jika ada yang mengkhianati pasangannya, Aku akan tinggalkan keduanya. (HR. Abu Daud 3358, ad-Daruquthni 2973).

Seorang pedagang atau seseorang yang sedang melakukan perserikatan harus berlaku jujur, dilandasi dengan keinginan agar orang lain mendapatkan kebaikan dan kebahagiaan sebagaimana ia menginginkannya dengan cara menjelaskan ketentuan syarat dan rukun yang terdapat pada akad mudhârabah. Nabi menjadikan kejujuran sebagai hakikat agama.

Lawan sifat jujur adalah curang, yaitu menonjolkan keunggulan barang (pada perdagangan) dalam akad mudhârabah dapat diartikan menyembunyikan kebohongan atau ketidakterbukaan dalam keuntungan atau dalam bagi hasil. Dalam hal ini bisa saja pihak BMT dapat tertipu karena ulah anggota. Imam al-Ghazali mengomentari hal ini, "Mereka telah memahami arti kejujuran, yaitu tidak rela terhadap apa yang menimpa temannya kecuali yang rela jika hal itu menimpa dirinya sendiri. Mereka tidak memandang hal ini sebagi keilmuan dan kedudukan yang tinggi. Mereka berkeyakinan bahwa kejujuran adalah syarat Islam yang mereka berikan dan yang termasuk dalam baiat mereka. Karena hal ini sulit dilaksanakan oleh bagian besar makhluk, maka mereka memilih untuk mengisolasi diri dari manusia dan menyendiri untuk beribadah. Sesungguhnya, melaksanakan hak-hak Allah dengan bermuamalat dengan manusia adalah suatu mujahadah yang tidak bisa dilaksanakan oleh orang-orang yang benar (lurus). ${ }^{18}$ 


\section{Fastabiq: Jurnal Studi Islam \\ ISSN 2723-0228}

Volume 1 Nomor 1 Juni 2020

Dalam ajaran Islam, kejujuran merupakan syarat paling mendasar dalam kegiatan bisnis. Rasulullah sangat menganjurkan kejujuran dalam segala bentuk aktivitas bisnis menurut Nabi, kejujuran akan membawa pada kebajikan akan pada surga. Demikian pula sebaliknya kebohongan akan membawa pada pelakunya pada keburukan dan akhirnya ke neraka. Rasulullah bersabda.

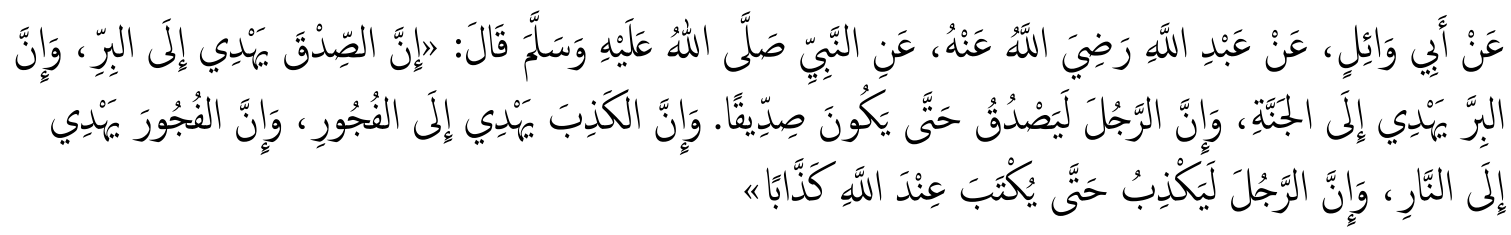

"Dari Abi Wail dari Abdullah r.a., dari Nabi Saw ia bersabda,"Sesungguhnya kejujuran membawa pada kebajikan dan kebajikan membawa pada surga dan sesungguhnya seseorangnya seseorang benar-benar jujur sehingga ditulis di sisi Allah sebagai orang yag jujur. Sesungguhnya kebohongan membawa pada keburukan dan keburukan itu membawa pada neraka dan sesungguhnya seseorang benar-benar dusta sehingga dicatat oleh Allah sebagai pendusta." (HR al-Bukhari dan Muslim).

Rasulullah melarang segala bentuk aktivitas bisnis yang dilakukan dengan penipuan karena penipuan dapat merugikan orang lain dan melanggar hak asasi dalam bisnis yaitu suka sama suka. Orang yang tertipu jelas tidak akan suka karena haknya dikurangi atau dilanggar. Bisnis yang mengandung penipuan misalnya jual beli sesuatu yang tidak diketahui hasilnya, atau tidak bisa diserahterimakan, atau tidak diketahui hakikat atau kadarnya.

b. Amanah dan profesional dalam bisnis

Di samping jujur, sikap amanah juga sangat dianjurkan dalam aktivitas bisnis. Kejujuran dan amanah mempunyai hubungan yang sangat erat karena orang yang selalu jujur pastilah amanah (terpercaya). Allah Swt memerintahkan agar umat Islam menunaikan amanat kepada orang yang berhak menerimanya dan jika memutuskan perkara agar dilakukan secara adil. Sebagaimana dalam firman-Nya:

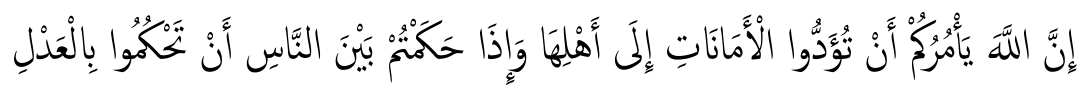

"Sesungguhnya Allah menyuruh kamu menyampaikan amanah kepada yang berhak menerimanya, dan (menyuruh kamu) apabila menetapkan hukum di antara manusia supaya kamu menetapkan dengan adil..." (Q.S. an-Nisa [4] : 58).

Dan dalam hadits Nabi Saw. Nabi bersabda.

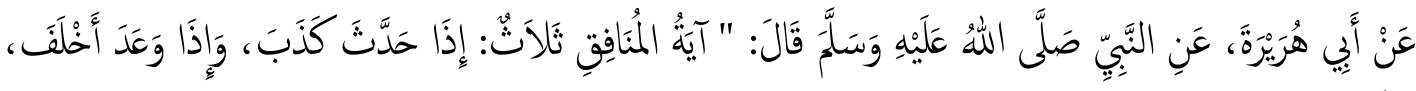

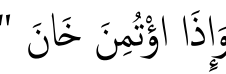

"Tanda-tanda munafik ada 3, yaitu jika ia diberi amanat maka ia berkhianat, jika berbicara ia berbohong dan jika ia berjanji maka dia ingkar." (HR. Al-Bukhari).

Dalam hal ini, khususnya pada akad mudhârabah yang mengemban perilaku amanah adalah anggota sebagai mudharib. Bagi mudharib perilaku amanah yang harus diterapkan antara lain: (1) amanah dalam menjalankan usahanya, sebagaimana yang telah disepakati pada saat kontrak perjanjian (2) amanah dalam menjelsakan dan merinci profit, dan (3) 


\section{Fastabiq: Jurnal Studi Islam}

ISSN 2723-0228

Volume 1 Nomor 1 Juni 2020

amanah dalam menerima risiko. Selain itu menepati janji-janji yang ada pada akad merupakan salah satu etika yang harus diterapkan oleh kedua belah pihak baik shahib al-mal maupun mudharib.

Amanah bertambah penting pada saat seseorang membentuk serikat dagang, melakukan bagi hasil dan sebagainya. Dalam hal ini, pihak yang lain percaya dan memegang janji demi kemashlahatan bersama. Jika salah satu pihak menjalankannya hanya demi kemaslahatan pihaknya, maka ia telah berkhianat.

c. Keterbukaan dalam bisnis

Keterbukaan dalam bisnis merupakan kunci keberhasilan. Apapun bentuknya, kejujuran tetap menjadi prinsip utama sampai saat ini. Transparansi terhadap kosumen adalah ketika seorang produsen terbuka mengenai mutu, kuantitas, komposisi, unsur-unsur dan lain-lain agar tidak membahayakan dan merugikan konsumen. Prinsip kejujuran dan keterbukaan ini juga berlaku terhadap mitra kerja. Seorang yang diberi amanat untuk mengerjakan sesuatu harus membeberkan hasil kerjanya dan tidak menyembunyikannya. Transparansi baik dalam laporan keuangan, maupun laporan lain yang relevan. Dalam kegiatan pembiayaan mudhârabah, transparansi saat penting dan mempengaruhi dalam akad. Dalam Mudhârabah, transparasi ini dilakukan pada transparasi;

1) Transparansi atau keterbukaan dalam melakukan pengajuan pembiayaan, tidak boleh adanya kebohongan dalam melampirkan persyaratan pembiayaan mudhârabah.

2) Transparansi dalam modal mudhârabah, modal yang diajukan oleh shaibul mal harus diketahui pula oleh mudharib. Kemudian nilai modal harus jelas apabila modal tidak jelas, berarti objek akad tidak jelas. ${ }^{19}$ Karena itu jika modal dalam bentuk aset, seperti bangunan atau lahan, harus dinilai terlebih dahulu.

3) Transparansi porsi bagi hasil.

Ibn Rusyd mengatakan,

Ulama dari berbagai negara sepakat bahwa amil tidak boleh mengambil keuntungan baginya, kecuali dengan melibatkan Rabbul Mal. Kehadiran Rabbul Mal adalah syarat pembagian harta dan amil berhak mengambil jatahnya. ${ }^{20}$

Dan jika terjadi perbedaan antara laporan mudharibi dengan perminyaan shahibul mal, maka yang menjadi acuan adalah laporan mudharib. Kecuali jika ada bukti bahwa mudharib melakukan penyelewengan. Karena posisi mudharib adalah amin (orang yang mendapatkan amanah). Dia dipercaya untuk mengelola modal milik shohibul mal. Sehingga status mudharib adalah yad al-amanah. ${ }^{21}$

Jika mudharib melaporkan bahwa usahanya tidak ada untung, sementara pemodal mengklaim ada untung, dan meminta bagi hasil. Maka di posisi ini, klaim pemodal harus diiringi dengan bukti. Sementara jika tidak ada bukti, yang dimenangkan adalah pernyataan mudharib. $^{22}$

d. Fathonah ( Cerdas) dalam mengelola usaha 


\section{Fastabiq: Jurnal Studi Islam}

ISSN 2723-0228

Volume 1 Nomor 1 Juni 2020

Dalam mengelola usaha tentulah mudharib yang sangat berperan. Hal ini dikarenakan bahwa tugas seorang mudharib adalah mengelola usaha yang diberikan oleh shahibul mal. Seyogiyanya, mudharib harus pandai dalam mengelola usaha yang dijalankan, baik dalam kegiatan operasional maupun dalam manajemennya.

Dalam menjalankan usahanya pastilah mudharib akan mengalami kendala yang tidak diinginkan, seperti terjadinya risiko-risiko yang ada dalam usaha. Risiko merupakan ketidakpastian pendapatan dalam suatu usaha. Risiko ini dapat terjadi karena adanya variabilitas harga jual karena semakin mudah harga jual suatu objek yang dijual berubah, semakin besar juga risikonya, bisa juga terjadi karena penggunaan biaya tetap yang tinggi, kemudian bisa terjadi karena manajemen yang tidak baik. ${ }^{23}$ Untuk mengatasi hal-hal tersebut maka mudharib perlu memiliki skill manajemen risiko agar risiko-risiko dapat diminimalisir. Risiko mungkin tidak dapat dihindari, namun sebisa mungkin mudharib dapat meminimalisir dengan menguasai skill manajemen risiko.

\section{Pembiayaan Akad Mudhârabah di BMT TAMZIS KCP Bandung Ibu Inggit Garnasih}

Produk Pembiayaan Mudhârabah Mezzo 1 (M1) merupakan produk pembiayaan dengan akad mudhârabah dalam range Rp.0 hingga Rp.25.000.000. Keberadaan produk Mudhârabah sebagai alternatif sumber modal serta alernatif dalam berinvestasi telah memberi banyak manfaat bagi perkembangan perekonomian masyarakat Indonesia. Terutama untuk usaha-usaha mikro dan kecil. Produk mudhârabah M1 membuka peluang dan kesempatan masyarakat kecil untuk membuka usaha. Pembiayaan mudhârabah M1 yang notabene nya berupa masyarakat kecil, umumnya merupakan masyarakat pemula dalam bidang bisnis. Adapun manfaat produk pembiyaan Akad Mudhârabah di BMT Tamzis yaitu Pihak KSPPS TAMZIS Bina Utama memperoleh peningkatan bagi hasil dan manfaat bagi pihak anggota salah satunya yaitu Anggota yang mendapat pembiayaan mudhârabah tidak diberatkan,karena pengembalian pokok usaha disesuaikan dengan cash flow atau arus kas nasabah. ${ }^{24}$

Adapun syarat-syarat pembiayaan mudhârabah. Pembiayaan Mudhârabah M1 pada KSPPS TAMZIS Bina Utama yang diperuntukkan bagi pengusaha mikro cenderung memiliki ketentuan dan syarat yang mudah. Kemudahan dalam pengajuan pembiayaan ini adalah salah satu keunggulan dari Koperasi Simpan Pinjam dan Pembiayaan Syariah, sehingga mempermudah anggotanya untuk mengembangkan usaha. Berikut syarat-syarat pembiayaan mudhârabah di BMT Tazmis. Syarat adalah permintaan yang harus dipenuhi oleh seseorang untuk dapat mengajukan Pembiayaan Mudhârabah M1 pada KSPPS TAMZIS Bina Utama. Berikut ini merupakan syarat yang harus dipenuhi untuk melakukan pengajuan pembiayaan mudhârabah M1: (a) Mengisi dan menandatangani formulir sebagai anggota KSPPS TAMZIS Bina Utama, (b) Menyerahkan fotokopi identitas diri beserta identitas suami/istri apabila sudah menikah, (c) Usaha yang dibiayai sudah berjalan minimal 1 tahun, (d) Bersedia mengangsur dengan ketentuan yang ditetapkan, dan (e) Memberikan bukti jaminan, dengan plafond pembiayaan tertentu. 


\section{Fastabiq: Jurnal Studi Islam \\ ISSN 2723-0228}

Volume 1 Nomor 1 Juni 2020

Ketentuan. Ada beberapa ketentuan yang harus disepakati anggota sebelum pemberian Pembiayaan Mudhârabah M1. Ketentuan-ketentuan tersebut diatur dalam akad yang meliputi:

a. Jumlah, Peruntukan dan Jangka Waktu Pembiayaan. Ketentuan ini untuk mengatur jumlah pembiayaan yang bersedia di berikan pihak KSPPS TAMZIS, serta peruntukan penggunaan pembiayaan tersebut. Penggunaan pembiayaan harus jelas, harus sesuai dengan syaiah.

b. Nisbah Bagi Hasil. Pemberian bagi hasil anggota kepada TAMZIS berdasarkan pendapatan kotor (revenue sharing). Pendapatan kotor per hari atau per bulan anggota merupakan pendapatan terkecil usaha anggota berdasarkan pengalaman usahanya, yang selanjutnya disepakati sebagai acuan bagi hasil usaha.Pengelolaan dan Pengawasan Usaha. Anggota selaku mudharib berhak untuk melakukan segala hal mengenai usahanya sesuai dengan ketentuan syariah dan kesepakatan kedua belah pihak tanpa keikutsertaan TAMZIS dalam manajemen, kecuali dalam hal pembinaan dan pengawasan. Anggota juga harus bersedia memberikan laporan atas hasil usahanya pada masa pembiayaan.

c. Agunan. Agunan diperlukan untuk menjamin keamanan serta agar terpenuhinya akad sebagaimana tujuan akad pembiayaan mudhârabah tersebut. Agunan yang biasa diberikan pada KSPPS TAMZIS Bina Utama berupa BPKB kendaraan, surat tanah, ataupun surat-surat berharga lainnya.

d. Penjaminan atau Ta'awun. Hal diperlukan untuk mengantisipasi berbagai risiko usaha yang mungkin terjadi, anggota harus mengikuti program ta'awun (penjaminan) dengan menyerahkan sejumlah dana hibah yang diperuntukkan sebagai sarana tolong-menolong diantara sesama anggota TAMZIS yang mendapat musibah selama jangka waktu pembiayaan.

e. Biaya-biaya. Seperti biaya administrasi, biaya materai, biaya survery, biaya notaris, dan biaya pengikatan.

\section{Deskripsi Umum Perusahaan:}

\section{Sejarah Baitul Maal wa Tamwil TAMZIS ${ }^{25}$}

TAMZIS dibentuk oleh sekelompok anak muda terdidik pada tahun 1992 di kecamatan Kertek, Kabupaten Wonosobo Jawa Tengah. Modal yang kecil, pengalaman yang minim serta letak geografis yang relatif berada bukan di sentra kegiatan ekonomi tidak menyurutkan tekad anak-anak muda ini untuk membangun perekonomian yang lebih adil sesuai syariah.

Pada tanggal 14 November 1994, TAMZIS mendapat status badan hukum dengan nomor 12277/B.H/VI/XI/1994 dari Departemen Koperasi. Berkat ijin Allah SWT melalui ketekunan, keyakinan dan kemampuannya berkomunikasi dengan masyarakat dan berbagai pihak, TAMZIS kini memiliki lebih dari dua puluh ribu anggota. Pelayanan kepada masyarakat yang semula hanya di garasi pengurusnya, kini telah memiliki kantor pusat yang representatif dengan beberapa kantor cabang dan kantor pembantu.

Pada tahun 2003 dengan prestasi dan kinerja yang terus meningkat, TAMZIS mendapat izin dari Departemen Koperasi Republik Indonesia untuk membangun cabang di berbagai kota di 
Fastabiq: Jurnal Studi Islam

ISSN 2723-0228

Volume 1 Nomor 1 Juni 2020

Indonesia. Selain di Wonosobo Jawa Tengah (kota asal didirikan), TAMZIS saat ini memiliki kantor di beberapa area, antara lain: Yogyakarta, Jakarta, Bandung, Banyumas, Magelang, Klaten, Semarang dan akan terus mengembangkan diri ke kota-kota lain.

Adapun untuk cabang TAMZIS yang berada di kota Bandung, pertama kali cabang di kota Bandung didirikan bulan Desember 2009. Sebelum menjadi TAMZIS Bandung Ibu Inggit Garnasih (BIG), awalnya bernama TAMZIS BOT (Bandung Otista), sebab kantornya yang terletak di Jl. Otista Bandung. Kemudian, TAMZIS BOT (Bandung Otista) pindah tempat ke Jl. Ibu Inggit Garnasih pada bulan Januari 2014, sehingga berganti nama menjadi Kantor Cabang Pembantu Bandung Ibu Inggit Garnasih (KCP BIG).

\section{Visi dan Misi Baitul Maal wa Tamwil TAMZIS :}

a. Visi. Tamzis memiliki Visi untuk menjadi lembaga keuangan mikro syariah yang utama terbaik terpercaya.

b. $\mathrm{Misi}^{26}$

1) Membantu dan memudahkan masyarakat mengembangkan kegiatan ekonomi produktifnya.

2) Mendidik masyarakat untuk jujur, bertanggungjawab, profesional dan bermartabat.

3) Menjaga kesucian umat dari praktek riba yang menindas dan dilarang agama.

4) Membangun dan mengembangkan sistem ekonomi yang adil, sehat dan sesuai syariah.

5) Menciptakan sistem kerja yang efisien dan inovatif.

\section{Profil dan Identitas KSPPS TAMZIS Bina Utama}

Adapun profil dan identitas KSPPS Tamzis Bina Utama adalah sebagai berikut

Nama Lembaga $\quad$ :Koperasi Simpan Pinjam dan Pembiayaan Syariah Tamzis Bina Utama (KSPPS).

Alamat : Jl. Inggit Garnasih (Ciateul) No. 62 D. Bandung.

Motto : :Happy Life, Happy Syariah”

Berdiri : Januari 2014

Badan Hukum $\quad:$ :12277/B.H/VI/XI/1994

No. Telp./Fax : : 02242823804

Email : info@tamzis.com / info@tamzis.co.id

Website $\quad$ www.tamzis.com

\section{Struktur Organisasi dan Uraian Jabatan Baitul Maal wa Tamwil Tamzis Kantor Cabang Pembantu Bandung Inggit Garnasih}

Adapun struktur Jabatan BMT TAMZIS KCP Bandung Inggit Garnasih adalah sebagai berikut:

Manager Area

Manager Marketing Cabang
: Jaka Pratama

: Aceng Marwan 
Fastabiq: Jurnal Studi Islam

ISSN 2723-0228

Volume 1 Nomor 1 Juni 2020

Manager Adiministrasi Cabang

Account Officer

Account Officer

Administrasi Pembiayaan

Marketing Kolektor

Teller
: Izza Pratiwi

: Lanu Parikin

: Asep Hendra

: Erina Budiarti

: Samsul Arifin, Heriyanto, Sani Nurohim, Fajar Nursidik.

: Ellyan Qhidam

\section{Mekanisme Pembiayaan Akad Mudhârabah di BMT Tamzis KCP Bandung Ibu Inggit Garnasih}

Pengajuan pembiayaan mudhârabah di KSPPS TAMZIS BINA UTAMA harus melalui beberapa tahapan dalam mekanisme pengajuannya. Berikut gambaran mekanisme pengajuan Pembiayaan Mudhârabah yang harus dilalui: ${ }^{27}$

\section{Gambar 1. Alur Prosedur Pengajuan Pembiayaan Mudhârabah}

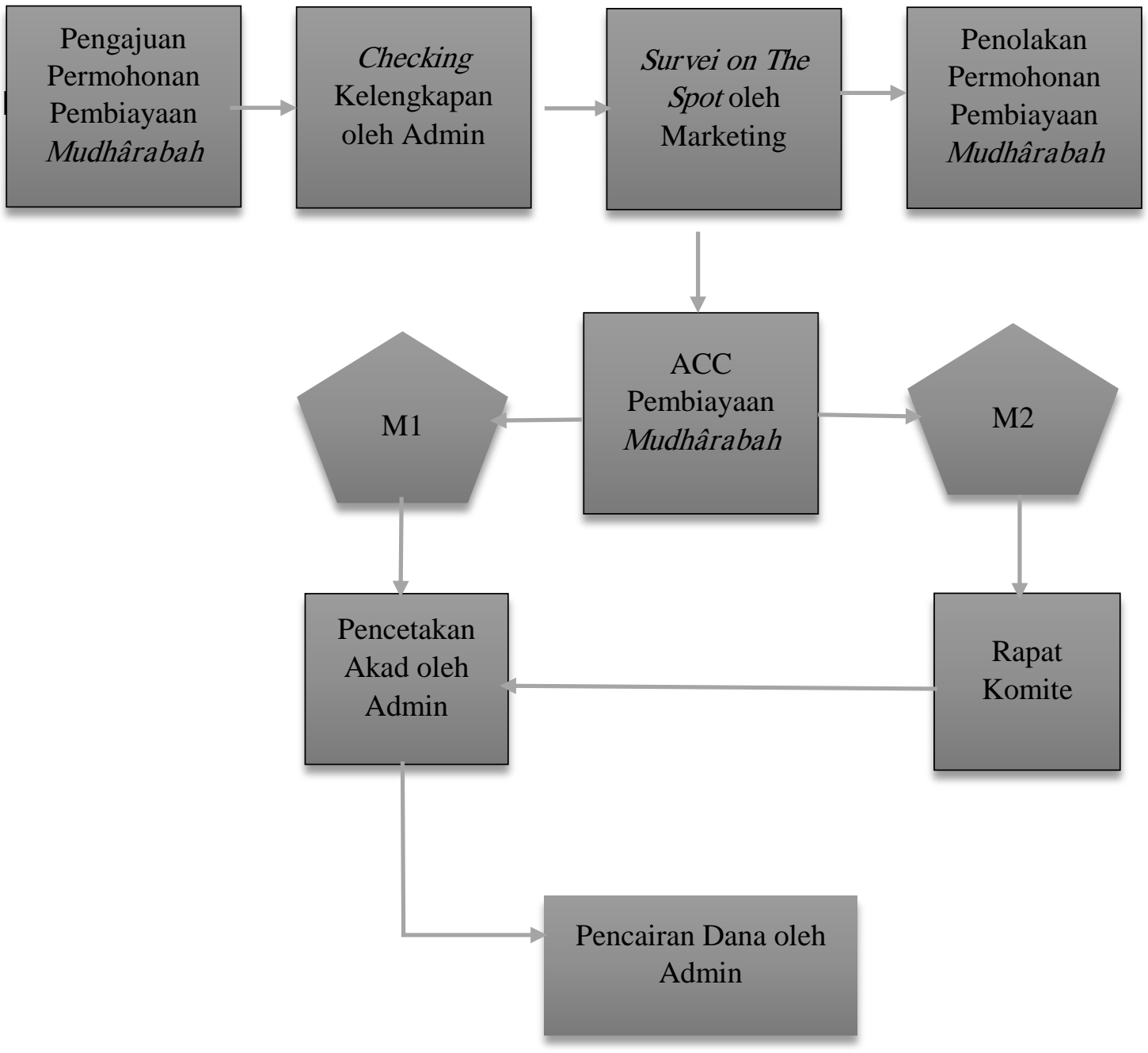




\section{Fastabiq: Jurnal Studi Islam \\ ISSN 2723-0228}

Volume 1 Nomor 1 Juni 2020

a. Pengajuan Permohonan Pembiayaan Mudhârabah. Pengajuan pembiayaan oleh nasabah ini mengharuskan nasabah membawa beberapa berkas yang dibutuhkan, antara lain; Formulir permohonan menjadi anggota TAMZIS (bagi anggota baru), Biodata anggota yang telah diisi lengkap, foto copy KTP, dan Foto berukuran $3 \times 4$.

b. Checking Kelengkapan Berkas Oleh Admin. Setelah berkas permohonan pembiayaan mudhârabah diserahkan ke pihak TAMZIS, bagian administrasi (admin) akan melakukan checking (pemeriksaan) terhadap kelengkapan berkas tersebut.

c. Survey On The Spot Oleh Marketing. Setelah syarat kelengkapan berkas telah terpenuhi, bagian marketing akan melakukan survey langsung ke lapangan (On The Spot). Hal ini dilakukan untuk mengetahui kondisi nasabah secara real serta untuk memastikan kesesuaian data nasabah dengan kondisi nasabah yang sebenarnya.

d. Penolakan Permohonan Pembiayaan. Penolakan pada permohonan pembiayaan ini terjadi apabila hasil survey On The Spot (OTS) dari bagian marketing tidak sesuai dengan kriteria yang ditentukan pihak TAMZIS.

e. ACC Permohonan Pembiayaan. Setelah pihak marketing yakin terhadap analisisnya terkait permohonan asabah, permohonan pembiayaan mudhârabah akan di ACC oleh Accout Officer (AO) dari marketing tersebut. Namun, penanganan permohonan pembiayaan mudhârabah tidaklah sama. Ada perbedaan penanganan sementara Pembiayaan Mudhârabah M1 dan M2. Pembiayaan Mudhârabah M1 yang telah disetujui atau telah mendapat ACC dari AO, bisa langsung dieksekusi ke tahap pencetakn akad oleh bidang administrasi. Berbeda dengan pembiayaan M2 yang masih harus dianalisis lebih dalam lagi oleh analyst dari pusat, yang hasil keputusannya ditentukan pada rapat komite.

f. Pencetakan Akad Oleh Admin. Berkas nasabah yang telah di ACC oleh bagian marketing akan disetorkan ke bagian administrasi untuk penginputan data nasabah. Setelah data nasabah diinput dan terkomputerisasi, akad dapat dicetak. Pencetakan akad ini hanya bisa dilakukan sekali, setelah input data dilakukan. Tidak bisa dilakukannya perubahan pada data nasabah yang telah diinput. Jika terjadi kesalahan dalam penginputan data nasabah, maka harus ada pengulangan penginputan data serta pencetakan akad.

g. Rapat Komite. Dalam rapat komite, dibuat keputusan untuk memberikan pembiayaan M2 atau tidak. Pertimbangan yang hati-hati ini sangat diperlukan, karena pembiayaan produk Mudhârabah M2 merupakan pembiayaan skala besar, yaitu di atas Rp.25.000.000.

Pencairan Dana Oleh Admin. Setelah input data dan pencetakan akad dilakukan, staff administrasi bagian legal bertugas untuk menemui anggota yang bersangkutan. Segala regulasi yang tertera di akad harus dibacakan serta diberikan penjelasan tambahan oleh admin, sehingga anggota dapat paham secara jelas terkait perjanjian yang akan dilakukan. Setelah anggota paham dan setuju, akad ditandatangani yang diikuti dengan pemberian dana cash kepada anggota.

Tabel

Anggota BMT TAMZIS KCP Bandung Inggit Garnasih (2019)

ETIKA BISNIS DALAM AKAD MUDHĀRABAH

Studi di Baitul Maal wa at Tamwil Tamzis kantor Cabang Pembantu Bandung Ibu Inggit Garnasih Annisa Eka Rahayu 
Fastabiq: Jurnal Studi Islam

ISSN 2723-0228

Volume 1 Nomor 1 Juni 2020

\begin{tabular}{|c|c|c|c|c|}
\hline No & Nama & No Anggota & $\begin{array}{l}\text { Status Pembiayaan } \\
\text { Mudhârabah } \\
\text { (Bagi Hasil)/Rp. }\end{array}$ & Keterangan \\
\hline 1 & Ika Fitria & Kowapi & 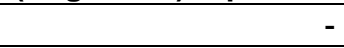 & Kurang Lancar \\
\hline 2 & Eni Rohaeti & Kowapi & 746.000 & Lancar \\
\hline 3 & Fajar Pratama & Kowapi & - & Kurang Lancar \\
\hline 4 & Nina Kurniasih & Kowapi & - & Kurang Lancar \\
\hline 5 & Bambang P & Kowapi & 6.100 .000 & Lancar \\
\hline 6 & Lukmana S & Kowapi & 17.850 .000 & Lancar \\
\hline 7 & Liliana Sudibjo & Kowapi & 1.100 .000 & Lancar \\
\hline 8 & Karnasih & Kowapi & - & Kurang Lancar \\
\hline 9 & Mahmudah Slamah & Kowapi & - & Kurang Lancar \\
\hline 10 & Rianto Arif & Kowapi & 651.000 & Lancar \\
\hline 11 & Lamiran Sugianto & Kowapi & 4.437 .500 & Lancar \\
\hline 12 & Maman Parman & Kowapi & - & Kurang Lancar \\
\hline 13 & Momon Sugih & Kowapi & 588.000 & Lancar \\
\hline 14 & Lamiran Santoso & Kowapi & 17.519 .000 & Lancar \\
\hline 15 & Intan Pramesti & Kowapi & 168.000 & Lancar \\
\hline 16 & Ricky Pramiyanto & Kowapi & 5.781 .000 & Lancar \\
\hline 17 & Sumiarto Masajid & Kowapi & 2.220 .000 & Lancar \\
\hline 18 & Diah Anggraini & Kowapi & 3.957 .000 & Lancar \\
\hline 19 & Utama Pratama & Aikma & 209.500 & Lancar \\
\hline 20 & Ina Sutiana & KWM & 3.000 .000 & Lancar \\
\hline 21 & Harry Jayanto & Kowapi & 7.182 .500 & Lancar \\
\hline 22 & Pramudi Jayadi & Kowapi & 2.794 .500 & Lancar \\
\hline 23 & Aep Saepudin & Kowapi & 1.014 .000 & Lancar \\
\hline 24 & Lilis Karlina & Kowapi & 84.000 & Lancar \\
\hline 25 & Irma Murtadi & Kowapi & 190.000 & Lancar \\
\hline 26 & Lena S. & Kowapi & 16.753 .000 & Lancar \\
\hline 27 & Mardiana Destianti & KWM & 5.880 .000 & Lancar \\
\hline 28 & Nurhayati & Aikma & 1.754 .500 & Lancar \\
\hline 29 & Yunas Ilham & Aikma & 9.299 .000 & Lancar \\
\hline 30 & Pramono & Kowapi & 1.520 .000 & Lancar \\
\hline 31 & Indah Lestari & Kowapi & 2.198 .000 & Lancar \\
\hline 32 & Sumirah & Kowapi & 784.000 & Lancar \\
\hline 33 & Dadang Sobari & Kowapi & 350.000 & Lancar \\
\hline 34 & Atep Rahmat & Kowapi & 1.120 .000 & Lancar \\
\hline 35 & Nani Imas & Kowapi & 858.000 & Lancar \\
\hline 36 & Lita Ambarwati & Kowapi & 52.500 & Lancar \\
\hline 37 & Tia A & Kowapi & 949.500 & Lancar \\
\hline 38 & Mudiarto Suparna & Kowapi & 1.320 .000 & Lancar \\
\hline 39 & Teteng Suparman & Kowapi & 274.500 & Lancar \\
\hline 40 & Teti Sodiqah & Kowapi & - & Kurang Lancar \\
\hline \multirow[t]{2}{*}{41} & Latif Mulyana & Kowapi & - & Kurang Lancar \\
\hline & TOTAL & & 118.685 .000 & \\
\hline
\end{tabular}

Data nasabah BMT TAMZIS KCP Bandung Inggit Garnasih di atas menunjukan bahwa kegiatan penerapan etika bisnis pada akad mudhârabah yang dijalankan telah menunjukan keberhasilan yang real dan penting. Artinya keberadaan BMT TAMZIS KCP Bandung Ingggit Garnasih dengan akad Mudhârabah-nya bernilai penting bagi para anggota yang merupakan para pedagang atau UKM (Usaha Kecil Menengah) di lingkungan KCP Bandung Inggit Garnasih. Ditunjukan dengan perputaran nilai akad Mudhârabah para nasabah (anggota) dari 32 orang dari 


\section{Fastabiq: Jurnal Studi Islam}

ISSN 2723-0228

Volume 1 Nomor 1 Juni 2020

keseluruhannya 41 orang $(78 \%)$ tersebut di atas bernilai nominal di atas seratus juta tepatnya Rp.118.685.000,- Nilai sebesar itu menunjukan bahwa sebagian besar nasabah yang menjalankan akad Mudhârabah dengan tertib dalam melakukan transaksi, ini sebagai bukti nyata bahwa penerapan etika bisnis islami yang amanah, jujur, dan profesional sebagai nilai-nilai prinsip syariat (etika bisnis islami) yang dijalankan, telah berhasil membuktikan keberhasilan yang signifikan.

\section{SIMPULAN}

Hasil penelitian ini menunjukan bahwa,

1. Etika bisnis Islam hadir sebagai wujud antisipasi terhadap banyaknya penyimpangan dan kecurangan dalam dunia bisnis misalnya penipuan, penggelapan, dan pemerasan yang kemudian menjadi latarbelakang munculnya etika bisnis. Dalam perspektif Islam bahwa berbisnis harus menjalankan etika, moral atau akhlak yang baik yaitu menerapkan sikap Jujur, Amanah dan profesional dalam bisnis, Keterbukaan dalam bisnis dan Fathonah (Cerdas) dalam mengelola usaha berpotensi membawa keberkahan syirkah dan keberuntungan. Penerapan etika dalam akad mudhârabah bertujuan agar tidak timbulnya sengketa dikemudian hari. Sehingga dengan etika bisnis Islam akan memberikan keuntungan bersama secara adil.

2. Etika bisnis Islam yang dijalankan dalam akad Mudhârabah di BMT TAMZIS KCP Bandung Inggit Garnasih telah menunjukan contoh keberhasilannya dalam membantu para anggota (nasabah) yang merupakan kalangan para pedagang di lingkungan Pasar ITC Kebon Kalapa. Keberhasilan dan keuntungan tersebut ditunjukkan dengan hasil akad Mudhârabah mereka yang menjalankannya sebanyak 32 orang dari 41 orang anggota (78\%) dalam tahun 2019 dengan nilai nominal sebesar Rp.118.685.000,- (seratus delapan belas juta enam ratus delapan puluh lima ribu rupiah). Suatu nilai nominal yang cukup besar dan berharga bagi para pedagang kecil (UKM) di lingkungan Pasar ITC Kebon Kalapa Bandung. 


\section{ENDNOTES}

${ }^{1}$ Yusuf Qardhawi, Norma dan Etika Ekonomi Islam, Depok: Gema Insani. Hal. 57.

${ }^{2}$ Idri, Hadis Ekonomi: Ekonomi dalam Perspektif Hadis Nabi, Depok: Kencana, 2017. Hal. 6.

${ }^{3}$ Ika Yunia Fauzia, Etika Bisnis dalam Islam, Jakarta: Prenada Media Group, 2014. Hal. 15.

${ }^{4}$ M. Nur Rianto Al-Arif, Lembaga Keuangan Syariah, Bandung: Pustaka Setia, 2012. Hal. 317.

${ }^{5}$ Andri Soemitra, Bank dan Lembaga Keuangan Syari'ah, Jakarta: Prenada Media Group, 2010. $\mathrm{Hal}, 452$.

${ }^{6}$ Irham Fahmi, Etika Bisnis: Teori dan Kasus, Bandung: Alfabeta, 2014. Hal 27.

${ }^{7}$ Faisal Badroen, Etika Bisnis dalam Islam, Jakarta: Prenada Media Group, 2014. Hal. 7-8.

${ }^{8}$ Nasrddin Baidan, Etika Islam dalam Berbisnis, Yogyakarta: Pustaka Pelajar, 2014. Hal. 7

${ }^{9}$ Idri, Hadis Ekonomi: Ekonomi dalam ... HIm. 347.

${ }^{10}$ Nurhasanah, Neneng, Mudharabah dalam Teori dan Praktik, Bandung: Refika Aditama, 2015. Hal. 74.

${ }^{11}$ Antonio Syafi'i, Bank Syari'ah Teori dan Praktik, Jakarta: Gema Insani, 2001. Hal. 95.

12 Jaih Mubarak dan Hasanudin, Fikih Mu'amalah Maliyah; Akad Syirkah dan Mudharabah, Bandung: Simbiosa, 2017. Hal, 159.

${ }^{13}$ Jaih Mubarak dan Hasanudin, Fikih Mu'amalah Maliyah; ..., Hal, 159.

${ }^{14}$ Dwi Suwiknyo, Ayat-Ayat Ekonomi Islam (Kompilasi Tafsir), Yogyakarta: Pustaka Pelajar, 2016. Hal. 185.

${ }^{15}$ Neneng Nurhasanah, Mudharabah dalam Teori dan Praktik, Bandung: Refika Aditama, 2015. Hal, 76.

${ }^{16}$ Wahbah al-Zuhaili, al-Fiqh al-Islami wa Adillatuh, Beirut: Dar al-Fikr al-Mu'ashir, 1997 Vol.V. Hal.3.928.

${ }^{17}$ Ammi Nur Baits, Pengantar Permodalan salam Islam, Yogyakarta: Pustaka Muamalah Jogja, 2018. Hal, 86.

${ }^{18}$ Yusuf Qardhawi, Norma dan Etika...Hal. 179

${ }^{19}$ Ami Nur Biaits, Permodalan dalam... Hal. 37.

${ }^{20}$ Abu al-Walid Muhammad Ibn Ahmad Ibn Rusyd al-Qurthubi al-Andalusi, Bidayatul al-Mujtahid wa Nihayah al-Muqtashid, Beirut: Dar al-Fikr, 2008, Jilid 2 hlm.194.

${ }^{21}$ Posisi pemegang harta ada yad amanah (mendapat amanah) dan ada yad dhamanah (harus menanggung semua risiko).

${ }^{22}$ Metode penyelesaian kasus semacam ini diajarkan dalam hadits dari Abdullah bin Amr bin Ash Radiyallhu'anhu, Nabi Saw bersabda: "Bukti itu menjadi tanggungkawab mudda'l dan sumpah menjadi pembela bagi mudd'a alaih." (HR Turmudzi 1391, Daraquthni 4358 dan disahihkan oleh Albani).

${ }^{23}$ Dadang Soebana, Manajemen Keuangan Syari'ah, Bandung: Pustaka Setia, 2018. Hal,212-213.

${ }^{24}$ Modul Materi Dasar 1 Angkatan 1 Tahun 2017 tentang Standar Operasional Porsedur Kantor.

${ }^{25}$ www.tamzis.com (diakses tanggal 6 Juni 2020 pukul 19:01)

${ }^{26}$ https://www.tamzis.id/page/1-company-profile (diakses pada tanggal 14 Juni 2020 pukul 19:07)

${ }_{27}$ Modul Materi Latsar 1 Angkatan 1 Tahun 2017 tentang Teknis Kerja Kantor Cabang. 


\section{REFERENSI}

Al-Qur'an Terjemahan Kontemporer. 2017. Bandung : PT Khazanah Intelektual.

Al-Arif, M. Nur Rianto. 2012. Lembaga Keuangan Syariah, Bandung: Pustaka Setia.

Al-Zuhaili, Wahbah. 1997. al-Fiqh al-Islami wa Adillatuh, Beirut: Dar al-Fikr al-Mu'ashir.

Badroen, Faisal. 2014.Etika Bisnis dalam Islam, Jakarta: Prenada Media Group.

Baidan, Nasruddin. 2014. Etika Islam dalam Berbisnis, Yogyakarta: Pustaka.

Baits, Ammi Nur. 2018. Pengantar Permodalan dalam Islam, Yogyakarta: Pustaka Muamalah Jogja.

Fahmi, Irham. 2014. Etika Bisnis: Teori dan Kasus, Bandung: Alfabeta.

Fauzia, Ika Yunia Fauzia. 2014. Etika Bisnis dalam Islam, Jakarta: Prenada Media Group.

Ibn Rusyd, 2008. Bidayatul al-Mujtahid wa Nihayah al-Muqtashid, Beirut: Dar al-Fikr.

Idri. 2017. Hadis Ekonomi: Ekonomi dalam Perspektif Hadis Nabi, Depok: Kencana.

Mubarak, Jaih dan Hasanudin. 2017. Fikih Mu'amalah Maliyah; Akad Syirkah dan Mudharabah, Bandung: Simbiosa.

Nurhasanah, Neneng. 2015. Mudharabah dalam Teori dan Praktik, Bandung: Refika Aditama.

Soebana, Dadang. 2018. Manajemen Keuangan Syari'ah, Bandung: Pustaka Setia.

Soemitra, Andri. 2010. Bank dan Lembaga Keuangan Syari'ah, Jakarta: Prenada Media Group.

Suwikyo, Dwi. 2016. Ayat-Ayat Ekonomi Islam (Kompilasi Tafsir), Yogyakarta: Pustaka Pelajar.

Syafi'i, Antonio. 2001. Bank Syari'ah Teori dan Praktik, Jakarta: Gema Insani. 